\title{
Study Abroad and Career Paths of Business Students
}

\author{
Tam y y rahood \\ Indiana University
}

Jennie Woolf

Indiana University

\section{Larisa Kruze}

University of Southern Maine

U.S. corporations continue to position themselves for international competition as the demand for cross-culturally competent employees continues to rise in response to globalization (Orahood, Kruze and Pearson, 2004, p. 117). Thomas Friedman explains that as a result of globalization "we are now connecting all the knowledge centers on the planet together into a single global network, which — if politics and terrorism do not get in the way — could usher in an amazing era or prosperity, innovation, and collaboration, by companies, communities, and individuals" (2006, p. 8). However, the U.S. struggles to find cross-culturally competent employees prepared to handle society's growing needs in Friedman's "flat world." "In a borderless marketplace, economic patterns and business practices in one region can determine the fate of a company on the other side of the globe. Increasingly, being a corporate leader demands an international background" (Schoeff Jr., 2006). At large corporations such as Proctor \& Gamble (P\&G), recognition of the value of such experience is commonplace; it is a "key ingredient you must have if you aspire to be a global player in the long term" (Siracusa, as cited in Schoeff Jr., 2006). Employees complete overseas assignments to gain a better understanding of how business is conducted around the world. Proctor \& Gamble believes that "exposing future P\&G leaders to new markets and cultures has produced a deep pool of managerial talent” (Schoeff Jr., 2006).

In fact, failure to gain international experience can prove to be detrimental to career success. Business graduates are no longer competing with just the 450,000 other American business graduates each year, or even with the approximately two million American university graduates each year, but they are now competing with millions of graduates worldwide (U.S. Department 
of Education, 2004). Multinational employers like Kimberly-Clark, Nokia, and Siemens value the talent they discover overseas because those "hires have a great deal to offer at a fraction of the cost of an expatriate. Furthermore, they usually have a far better grasp of the market and an intimate understanding of the language and culture of their homeland" (Ruiz, 2006 ). Therefore, it is vital for business students, in particular, to have overseas experience during college, before they enter the competitive workforce.

Business students not only need to gain international experience, they also need to effectively market these experiences to potential employers. In 2006, the Institute of International Education, the German Academic Exchange Service, the British Council, and the Australian Education Office commissioned a study to determine the demand for study overseas from American students and employers (J. Walter Thompson Education, 2006, p.1). The results showed that "employers' most important selection criteria in recruiting candidates are interpersonal skills" (J. Walter Thompson Education, 2006, p.2). The majority of alumni from study abroad programs gain interpersonal skills from the need to communicate with people from different backgrounds, cultures, and languages. The study found that although employers agree that studying abroad helps to gain interpersonal skills, ironically, they do not specifically seek out candidates with study abroad experience unless they are hiring for a job which requires cross-cultural skills. This may indicate that recruiters are not yet recognizing the positive link between the skills they seek in a candidate and the interpersonal skills that study abroad alumni gain from their overseas experience. (J. Walter Thompson, 2006). The study also revealed the top skills that recruiters feel those with international experience acquire: cross-cultural communication skills, flexibility, autonomy, leadership skills, innovation, maturity, presentation skills, ambition, independence, and cultural awareness. The study's sponsors are now undertaking marketing efforts to show employers that study abroad participants are exactly the type of employees they seek.

The Kelley School of Business (KSB) at Indiana University (IU) recognized early the benefit of an international experience for its students. (KSB defines an international experience as consisting of at least 6 weeks outside the U.S., and including an academic component.) In 1981, the KSB implemented its first study abroad experience strictly for undergraduate business students. Following that initial program, KSB added programs in Europe, Asia, Mexico, and Brazil. KSB students may now choose from sixteen semester programs, six summer programs, various short-term programs and one Dual Degree with the European School of Business in Germany. KSB also has its own career services 
specifically designed for business students. One of its stated objectives is to empower a diverse student population to actively manage their career choices in the global marketplace.

Approximately $48 \%$ of KSB students participate in a study abroad experience, in part due to the international dimension requirement (IDR) of all business students. In order to satisfy this requirement, which was implemented in 1998, KSB students must complete six hours of an international dimension in one of four categories: 1) two years of foreign language; 2) international business and economics coursework; 3) area studies coursework; or 4) participation in a minimum six-credit overseas study program. The IDR has directly contributed to the growth in numbers of KSB students who choose to study abroad (Sideli et al., 2003).

To assess the impact of business students' international experience during college on their post-graduation careers, the authors of this study surveyed KSB alumni who were five to ten years into their careers. The goal of the research was to determine the impact of international experience on alumni's career paths. In addition, the survey sought to compare the career paths of alumni who studied abroad to those who did not study abroad.

\section{Research Questions}

Little research has considered the effects of study abroad experiences on students' career choices. Likewise, there is a lack of research on how study abroad experiences affected professionals later on in their careers. As a result of their 2004 study, the authors concluded that further research was needed in the area of career interests and choices among alumni of study abroad programs at the Kelley School of Business (Orahood et al., 2004). Having determined that business students who study abroad have a greater interest in working for a company with an international dimension, the authors wanted to find out if, when five to ten years out of school, those same students were more likely to be working in a company with an international dimension than students that did not study abroad. The following research questions guided the follow-up investigation:

1. Were alumni career interests, plans, and job searches affected by studying abroad in college?

2. Was alumni career preparation and development affected by studying abroad in college?

3. Did study abroad alumni use their undergraduate international experience during the job search process? 


\section{Methods}

\section{Research Design and Instrument}

The authors developed a survey instrument for KSB alumni who were five to ten years past their undergraduate degree. The alumni were asked to selfassess the impact of studying abroad on their career interests, plans, and choices. The 42 questions and statements were developed based upon previous study abroad and career planning research and included both closed and open-ended formats. Questions asked participants to report the following information: their work history since graduation, whether they felt their study abroad experience was an asset in finding a job, the location and nature of all jobs since graduation and whether or not the positions contained an international dimension.

Statements asked participants to evaluate their level of interest in working for a company with an international component post-graduation on a fivepoint scale from "Strongly Interested" to "Not Interested." Topics included: interest in working for U.S. companies with an international focus, interest in working for a multinational company with overseas offices, and level of interest in working in a foreign country. Alumni were also asked to self-assess their foreign language skill level in written, spoken, and listening competency by utilizing a scale of one to five with five representing fluency.

To reach the desired participant pool, the survey instrument was administered through a website. Identification mechanisms guaranteed that participants could submit only one web-based survey. A scripted e-mail message invited the alumni to participate in the study, asked them to complete an online survey, and directed them to the website link. Those who did not complete the survey after the initial e-mail received a second e-mail reminder approximately 14 days later.

\section{Respondents}

The population for this study included approximately 3,000 KSB alumni and specifically targeted those who had completed their undergraduate degree five to ten years earlier. During the three-week collection period, 458 participants completed the survey, resulting in a 16 percent response rate. There were 41 responses from individuals who indicated holding an F1 or J1 visa, which indicates that they were an international student. These respondents were not included in the data analysis because we wanted to limit the study to American alumni who studied overseas. The 417 remaining survey responses were sorted to distinguish between students who participated in a study abroad experience of six weeks or more and those who did not study abroad. 


\section{Findings and Discussion}

In their initial study in 2004, Orahood, Kruze, \& Pearson found that business students' career choices are heavily impacted by their study abroad experience. They discovered that study abroad participants were significantly more interested in working for a company with an international focus (61\%). than those business students who did not study abroad (27\%). In addition, the desire these students had to work in a foreign country was significantly greater for those who studied abroad (41\%) than those who did not (17\%).

We anticipated that the follow-up survey results would prove that business majors who studied abroad in college would be more likely to follow a career involving an international dimension than those who did not study abroad in college. However, the findings surprised us. We found that although business students who studied abroad tend to have a significantly larger interest in working for a company with an international component (83\% vs. 68\%), the number of alumni who found work with international clients/customers was greater for those who did not study abroad (26\% vs. 33\%). Only $20 \%$ of alumni who studied abroad were not interested in working abroad versus $46 \%$ of non-study abroad alumni.

We analyzed several reasons that could explain why the data did not prove our hypothesis. One possible explanation is that business today is inherently global, which means that even those who do not have a specific interest in international business are bound to find international aspects to their job. We noticed a consensus among alumni that they did not feel that their experience abroad impacted their career plans, but it increased their interpersonal skills, making them more outgoing and changing their outlook on life. One alumnus said: "My study abroad experience on my resume absolutely had an impact in my gaining employment, but did not impact my career plans." Another said, "Culturally it changed my life, but by the time I went abroad I had decided on a major."

Second, specialization within the business curriculum closely relates to the study abroad experience for business students. Students who major in accounting and finance, for example, must choose that route early in their undergraduate schooling and have limited flexibility in coursework because of the large number of specified credits. It is not unusual for such majors to pre-determine a firm or industry in which they want a career. In contrast, students in other majors may be more likely to re-focus their career paths after a study abroad experience. These other majors have broader course options, which allow changes in career paths. 
Therefore, one of the major conclusions from this study was that studying abroad on business students tends to have more impact on personal growth and development rather than on career choice. Although many alumni who completed the survey agreed that the experience was invaluable, most of them stated that they had made major decisions on career choices prior to the study abroad experience, so it had a minimal impact on where they ended up working. The following quotes illustrate this point:

"I would highly recommend an overseas study program for everyone, including my own children someday. I feel that the experience did more for my emotional growth and confidence than it did for my intellect."

"It's my belief that my international experience was one of the best things I have ever done in my life. I can confidently say that I would be a very different person had I not gone to London."

There were also some who felt it was necessary to obtain international experience, regardless of personal interest:

"[I] Strongly support international studies/study abroad programs... it is no longer a nice (sic) to have but mandatory for today's international business culture."

"My study abroad experience on my resume absolutely had an impact in my gaining employment, but did not impact my career plans."

"Well-roundedness" was another term used in numerous responses. Even though studying abroad may not impact alumni's professional destination, study abroad builds strong character and develops communication and interpersonal skills. This is illustrated in the following responses from alumni:

"I strongly believe that my study abroad experience has made me a more well-rounded individual. It has introduced me to living and learning in another country. I consider it an invaluable experience."

"Studying abroad forces one to mature quickly and discover one's self. Due to the aforementioned, you gain a more well-rounded view of the world and increased self confidence." 
"Studying abroad is a wonderful experience, as it makes one a more wellrounded individual. View it as a privilege and an investment in [yourself]."

"I think my experience abroad expanded my thought process, and made me a more open minded and well rounded individual, that has helped me in my every day work and personal relationships."

One major conclusion that can be drawn from this survey is that business students who study abroad are more receptive to the idea of working abroad than those who did not study abroad (20\% to 46\%). We also discovered that students from the Midwest that studied abroad at KSB are more likely to leave the Midwest when choosing careers than those who did not study abroad (70\% to $50 \%$ ). These results show that business students who chose to study abroad are more likely and willing to adapt to new and unfamiliar situations than those who did not study abroad. Some of the alumni comments corroborate this theme:

"My studies abroad were very valuable. However, it was not the difficulty of the class work or even the material of the classes, but the experience that was so important. I think interacting with students from all over the world, experiencing the feeling of being the only American in a class, and seeing America/Americans from other view points, made me a more well rounded person. My classes were light and fortunately I had the opportunity to travel, which provided a whole different skill set not found in the classroom. Overall, a very important experience which I feel lucky to have had."

“Although I have not had the opportunity for int'l assignments in my career, I enjoy traveling internationally and working with individuals from other cultures. In my opinion, it is important for individuals to experience other countries/cultures so that they become aware of how ethnocentric our culture is in the US. Students should be encouraged to study/travel abroad as those experiences create well-rounded individuals in both the local and business communities."

“My first years out of college, I wasn't as interested in a company with int'l focus. However, as I have gotten more experienced, I think it would be an exciting challenge to move abroad and experience sales from a different vantage point." 


\section{Conclusion}

In conclusion, we did not find a causal link showing that study abroad significantly impacted alumni's career paths. However, we did find that the transferable skills (communication, flexibility, adaptation, etc.) that alumni gained while abroad were considered valuable as life skills. Therefore, it is important to continue to educate employers on the importance of these skills, and the fact that study abroad participants value them.

As a result of our findings, we recommend that students are introduced early to study abroad options, even as early as the first semester of the freshman year. One reason for non-participation is due to lack of pre-planning. Early planning will enable students to fit an overseas experience into their fouryear plan. Since it is advantageous for students to demonstrate cross-cultural competency and other international skills when job-seeking, and throughout a career, overseas study is one more asset to bring to the table.

In addition to educating employers about the transferable skills gained during study abroad, advisors and administrators also need to work closely with career services offices. Campus career service offices can be an important partner to emphasize to students and employers the importance of foreign language and immersion experiences and the benefits of study abroad. Students reluctant to take classes overseas, or in a foreign language, might be convinced if they could see tangible evidence, supported by the career service office, that employers seek the skills gained by studying abroad. The career service office can be advised about the merits of study abroad, by sharing some of the existing literature on what employers are looking for in candidates, and how study abroad alumni are able to demonstrate these skills.

As the number of business opportunities abroad continues to increase, we can hope to see a direct correlation with the number of business students going abroad. In today's global economy, we should expect that employers will seek students with international experience, and alumni career paths will proceed accordingly. 


\section{References}

BusinessWeek.com. (2006, December 27). Getting up to speed at Kelley. Retrieved June 21, 2007, from BusinessWeek Web site: http://www.businessweek.com/bschools/content/dec2006/bs20061227_051407.htm

Friedman, T.L. (2006). The World Is Flat. Farrar, Strauss and Giroux, New York.

J. Walter Thompson Education. (2006). An exploration of the demand for study overseas from American students and employers. Sponsored by: Institute for International Education, the German Academic Exchange Service (DAAD), the British Council, and the Australian Education Office.

Kolb, D.A. (1984). Experiential learning: Experience as the source of learning and development. Englewood Cliffs, NJ: Prentice Hall.

Mission statement. (n.d.). Retrieved June 14, 2007, from Indiana University, Kelley School of Business Web site: https://ucso.indiana.edu/cgi-bin/missionstatement.cfm

Orahood, T. (2004). The Impact of Study Abroad on Students' Career Goals in Frontiers: The interdisciplinary journal of study abroad. X, 117-130.

Ruiz, G. (2006, April 10). Kimberly-Clark developing talent in developing world markets. Retrieved June 14, 2007, from Workforce Management Web site: http://www.workforce.com/section/09/feature/24/33/52/243354.html

Schoeff Jr., M. (2006, April 10). P\&G places a premium on international experience. Retrieved June 14, 2007, from Workforce Management Web site: http://www.workforce.com/section/09/feature/24/33/52/index.html

Sideli, K., Dollinger, M., \& Doyle, S. (2003). Successful Recruitment of Business Students For Study Abroad Through Program Development, Curricular Integration and Marketing. In G.T.M Hult and E.C. Lashbrook (Eds.), Study Abroad Perspectives and Experiences From Business Schools, Boston, JAI.

Study abroad opportunities. (n.d.). Retrieved June 14, 2007, from Indiana University, Kelley School of Business Web site: http://www.kelley.iu.edu/ ugrad/overseas/programs.cfm

U.S. Department of Education, National Center for Education Statistics, 200304 Integrated Postsecondary Education Data System (IPEDS), Fall 2004. Table 252. Bachelor's, master's, and doctor's degrees conferred by degreegranting institutions, by sex of student and field of study: 2003-2004. Retrieved from http://nces.ed.gov/programs/digest/d05/tables/dt05_252. asp on June 14, 2007. 